\title{
Active Learning: English Language Teaching via Write Share Learn Strategy
}

\author{
Cavide Demirci ${ }^{1}$, Mehmet Akcaalan ${ }^{2}$
}

\section{ARTICLE INFO}

Article History:

Received 11.12.2019

Received in revised form

05.05.2020

Accepted

Available online 01.07.2020

\begin{abstract}
The aim of investigation is to examine opinions of 11th grade high school students via "write, share, learn strategy" of active learning approach in language teaching. The students were asked some questions so as to determine their opinions for the strategy. The questions for the students were created by three English teachers and a university instructor. The students in the research studied in the 11th grade and their class size consisted of 20 students. The application of the write, share and learn strategy was lasted in 5 lessons time in two weeks. So as to apply the active learning strategy smoothly, the music lesson classroom of the school was used by admittance of school principal. It may be understood that the students' satisfaction about the lesson was compelled to rise by the active learning strategy. Write, share and learn strategy of active learning pedagogy has an importantly strong effects on students' learning perceptions. The results demonstrate that compounding these aspects of active learning may support teachers to teach efficaciously and so students can acquire actively in learning settings.
\end{abstract}

C IJERE. All rights reserved

Keywords: ${ }^{1}$

Active Learning, English Language Teaching Write Share Learn Strategy.

\section{INTRODUCTION}

In the last five decades, plenty of optional learning activities have been created or constructed such as active learning, problem based learning and experimental learning (Bain, 2004; Carvalho, 2016; Slavich and Zimbardo, 2012; Sroufe and Ramos, 2015; Werner, Scovotti, Cummings and Bronson, (2018). Teaching is a way of facilitation for the students to participate in learning activity. It is no longer something just loading information in learners' head (Christensen, Garvin and Sweet, 1991; Hyun et al., 2017). An idea "pedagogies of engagement" facilitated to enhance student participation in classrooms. Therefore, various sorts of learning approaches or methods have come to light like collaborative learning and problem-based learning so as to afford learner participation in classrooms. Active learning pedagogy refers to these methods emerged upon here (Prince, 2004; Prince and Felder, 2007; Hyun, Ediger, and Lee, 2017; Hyun et al., 2017).

Active learning has many definitions in terms of various point of views when looked up the literature of the education field. According to Prince (2004) active learning is a teaching method that involves and encourages the learners as active contributor in the learning environment. In this context the learners are a part of learning, and the teacher enables this learning environment. Students creates their own knowledge structure, so learners' point of view to learning and knowledge are crucial, and students show up and takes the responsibility of their own learning nature (Prince, 2004; Virtanen, et al 2017). In this new era, the skills taught at schools call for the instructors to be able to involve active learning in the classrooms such as leading students to take responsibility of their own learning and comprehending, creating, examining and commenting the knowledge in terms of various components (O'Grady et al., 2013; Virtanen et al., 2017). Scheyyens et al. (2008) asserted that the best definition of active learning can be achieved by telling what active learning is not. Therefore, when students simply sit and listen to the instructor in an inactive position, it cannot be called as active learning pedagogy. What crucial in active learning is focusing on developing the abilities of students rather than just pouring knowledge into learners' head (Christensen, Garvin and Sweet, 1991; Hyun et al., 2017). In this approach students are required to step up to a more developed thinking skills and triggered to engage in activities so as to improve their abilities and point of view (Bonwell and Eison, 1991; Demirci and Düzenli, 2017). By another perspective, active learning has been defined as "seeking new information, organizing it in a way that is meaningful, and having the chance to explain to others" (Allen and Tanner, 2005, p262; Khan et al., 2017). It has been found that utilizing this kind of techniques of active learning develops learners' comprehension in addition to their approach to learning (Vygotsky, 1978; Chickering, Gamson, 1987; Armbruster et. al, 2009; Khan et al., 2017). An effective learning calls for that learners have to not also be predominately engaged in improving their learning but also require a learning environment to have a mutual culture (Bruner, 1986; Stover and Ziswiler, 2017). Lumpkin and

${ }_{1}^{1}$ mehmetakcaalan@gmail.com Eskisehir Osmangazi University orcid.org/0000-0002-6977-3728
2 orcid.org/0000-0003-4789-4286 Eskisehir Osmangazi University2 
colleagues (2015, p. 123; Adkins, 2018) described active learning as any event triggering learners to get involved in learning approaches holding them with the lesson material and encouraging critical thinking while they participate in activities beyond the lesson. Active learning is described as any activity related to a course that all learners in a learning environment are required to perform more than just watching, listening and jotting down (Felder and Brent, 2009, p. 2; Stover and Ziswiler, 2017).

The other important aspect of active learning is the instructor who leads the students into learning actively. According to Bates and Townsend (2007) transformation of instructors is a key factor for the same process of the schools. In many aspects all learning attempts can be called as active. However, what is mentioned here as active learning is the rank of participation of learners in the teaching event. As shareholders of teaching and learning atmosphere, instructors and students need to undertake themselves as a vigorous company that they participate in a responsibility for teaching and learning (Demirci, 2017). Also, the active learning classrooms generally afford the learners in a learning atmosphere with technological equipment like computers that help teachers to apply active learning strategies like write, share, learn strategy (Demirci, 2003). However, constructing an active learning classroom is a difficult and expensive process. Education directors at higher education institutes claim responsibility for a great amount of investment such as renovating the active learning classroom environments, providing the classrooms with projectors, interactive flat panels, round tables, chairs and microphones, financing the technological background like laptops, software or projectors, and building up all this equipment properly (Stover and Ziswiler, 2017).

Personal attributes of students and their level of learning eagerness are some essential factors in active learning. In active learning classrooms are required to be well organized in terms of physical condition and learning atmosphere so as to afford the requirements of students and to construct facilities for learners with the help of impelling them to be involved in an interaction with each other. Visual and audial instructional equipment are necessarily applicable in this education method and the context of the lesson is to be in relationship with real life. The most essential factor here is to facilitate learners with required time and environment to get into interaction and communication with each other (Orak and Demirci, 2018). All in all, a proper mix of knowledge and skills is the main target of active learning. That's the reason that active learning is not something like inactive learning (Naithani, 2008; Demirci, 2017).

The objective of this case study is to determine opinions of $11^{\text {th }}$ grade high school students towards "write, share, learn strategy" of active learning pedagogy in English language lesson. The research questions of this investigations are.

a. How do the $11^{\text {th }}$ grade high school students feel themselves in the course of the lesson with the write, share, learn strategy?

b. Have the $11^{\text {th }}$ grade high school students ever had lessons with the write, share, learn strategy?

c. What are the favorable and unfavorable sides of the write, share, learn strategy in English language lesson in the point of view of $11^{\text {th }}$ grade high school students?

\section{METHOD}

This case study was performed so as to examine opinions of $11^{\text {th }}$ grade high school students towards "write, share, learn strategy" of active learning pedagogy in English language lesson. The reason of the preference of $11^{\text {th }}$ grade for this study is all about the school management' suggestion and positive interaction between English teacher and 11 th grade students. Case study requires the individuals to examine how they see themselves according to their experiences, to investigate the reasons their perceptions and emotions. A case may consist of a unique individual, an institute like a school, university, department or a company likewise a community or a group such as a family and a class of students. The most important element here is to determine and plan a research related to the intended subject undertaken by the researcher (Gillham, 2000; Saban and Ersoy, 2016). 
At the end of the lesson, the write, share, learn strategy was performed successfully. As this investigation is aimed to determine opinions of $11^{\text {th }}$ grade high school students towards "write, share, learn strategy" of active learning pedagogy in English language lesson, the students were asked two questions with two probing questions so as to define their opinions for the strategy. The questions asked by the teacher after the last phase were:

1. How did you feel yourself in the course of the lesson with the write, share, learn strategy? Explain with examples.

2. Have you ever had lessons with the write, share, learn strategy?

a. If "Yes" which lessons did you have with this strategy?

b. What are the favorable and unfavorable aspects of todays' lessons for you?

The questions asked to the students after the end of the active learning strategy were produced by the help of three English language teachers and a university instructor.

The students' answers were coded as "Students' Positive Emotions on the Active Learning Lesson", "Students' Negative Emotions on the Active Learning Lesson", "Positive Effects of Active Learning on Students' Learning", "Positive Opinions of the Students about Sitting Order of Seating", "Negative Opinions of the Students about Sitting Order of Seating", "Any Experience about Active Learning Activity Beforehand", "Students' Active Learning Lesson Experience". The frequencies of the students' answers were calculated and demonstrated in a table in the results section.

The current research was applied in a central high school of a province in the Marmara Region in Turkey. The students who were involved in the research studied in the $11^{\text {th }}$ grade and their class size consisted of 20 students. All the students were identified as male. The students' age of $11^{\text {th }}$ grade ranged from 16 to 18 . Because the high school chosen for the investigation was for only male students officially. The application of the write, share and learn strategy was lasted in 5 lessons time in two weeks. In order to apply the write, share, learn active learning strategy properly, the music lesson classroom of the school was utilized by courtesy of school administration. As the music lesson classroom of the school was comparatively appropriate for a circular order of seating and in the scope of this study the students would feel comfortable to act suitable for the active learning strategy, switching from a traditional classroom into a classroom like the one's of active learning pedagogy was considered to be effective in terms of the productivity in the research. The music lesson classroom seats are also portable and tablet armchair. In the circular order of seating students sit in a circular shape to see each other clearly in the classroom without any desks as blinders (Demirci, 2003).

The activity called "write, share, learn strategy" of active learning pedagogy was utilized in this research. In this strategy students receive a question and write an answer for the received question. Later they share their written respond with their classmates. By means of this strategy used here the main objective is to acquire basic writing skills. This strategy includes five phases to utilize in an active learning class (Harmin, 1994; Demirci, 2003; as cited in Saban, 2000).

Before the start of the write, share, learn strategy, the students were conferenced shortly (about $10 \mathrm{~min}$ ) about the subject to be used in the lesson. In this lesson, used to structure as an achievement was preferred so as to teach according to the official lesson plan. After a short instruction without boring the students, first phase of the strategy was initiated, and the teacher asked to the students a question like "What did you use to like in your childhood?". While they were thinking about a proper answer for the question, they were handed out the papers which had pictures on it in order to trigger their imagination on the way of writing an appropriate answer to the received questions by teacher. Each paper delivered to the students included a different picture in order to prevent cheating among students and boost them to produce various answers. The students were given enough time so as to take down their answers silently. In the second phase of the activity, the teacher observed that a few students finished jotting down their answers, so he wanted all the students to stop writing for a short time. Then the teacher wanted to hear an answer from the first volunteer student. A few students answered the questions related to the pictures on the papers given them like "I used to join social activities at school". In order to prevent students to give the same answers, the teacher stopped the first phase of the activity in a short time. In the third phase of the activity, the teacher asked to the students to get in pairs to share their answers with their peers in a very short time. Some students who could 
not find a peer or were not eager to find a peer as a result of their teen ages got help from their teacher immediately. The teacher boosted the students' energy by cheering like "you have 3 minutes left", "hurry up guys!" or "come on!". Even if some of the students initiated the discussion new, the teacher stopped the phase on time. In the fourth phase the teacher asked students "Who wants to share an answer of his friend?" or "who wants to share a question with the structure use to?" In order to finish this phase, the teacher shared his own answer for the students. In the fifth and the last phase of the strategy, the teacher summarized the phases committed in the course of the lesson with the students and asked them what they learned in that lesson.

\section{FINDINGS}

Table 1 below demonstrates the frequencies and percentages of the codes inferred from the students' answers to the questions asked in the end of active learning activity.

\begin{tabular}{llllllll}
\hline Students' & Students' & Positive & Negative & Positive & Negative & Any & Students' \\
Positive & Negative & Effects of & Effects of & Opinions & Opinions & Experience & Active \\
Emotions & Emotions & Active & Active & of the of the & about & Learning \\
on the & on the & Learning & Learning & Students & Students & Active & Lesson \\
Active & Active & on & on & about & about & Learning & Experience \\
Learning & Learning & Students' & Students' & Order of & Order of & Activity & \\
Lesson & Lesson & Learning & Learning & Seating & Seating & Beforehand
\end{tabular}

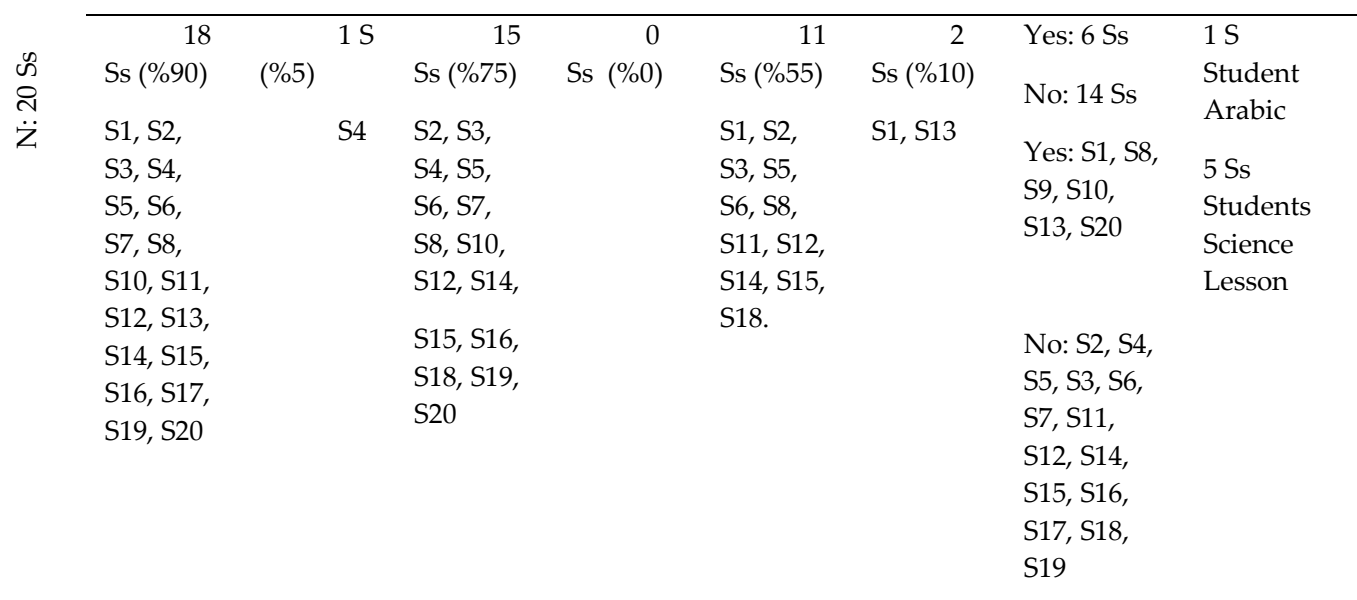

According to the table above it can be inferred that there is a great amount of differences between the students' positive emotions and negative emotions on the active learning activity. $90 \%$ of the students in this classroom have positive emotions on the active learning activity. S5 explained this situation as "I felt myself energetic and active during the lesson time." $5 \%$ of the students have negative emotions on the active learning activity. S4 asserted his dissatisfaction as "It was a little boring in the beginning, but I liked it because the activity was nice". S4 uttered his both satisfaction and dissatisfaction with this opinion. So, there are only two students $(\mathrm{S} 9, \mathrm{~S} 18)$ who did not take down any opinion about their positive or negative emotions about the active learning activity.

Another finding in this paper is about positive and negative effects of active learning on students' learning. As it is seen in the table the most different results are between positive and negative effects of active learning on students' learning. $75 \%$ of the students reflected their positive opinions of the active learning activity on their learning here. One of the students, S3 expressed his positive opinions best with these words "A long time later we had a real, interactive lesson... I had a lesson without any distractors". Five students S1, S9, S11, S13 and S17 did not reflect their opinion about their learning from the active learning activity. On the other hand, none of the students expressed any negative opinions of the active learning activity on their learning in this case study. 
Sitting order of this lesson is an essential element investigated in this research. It can be seen the least differences in this study between positive and negative opinions of the students about sitting order of seating. $55 \%$ of the students included in the examination signified their positive opinions of the students about circular order of seating. S1 explained his satisfaction about circular order of seating as "I liked the order of seating because single seating was comfortable, and I could see my friends' face easily". $10 \%$ of the students in other words two students were not happy with the circular seating order. They explained their dissatisfaction with these words: S13 "As the teacher was right in front of me, I couldn't feel comfortable myself while sitting". S1 reflected his both satisfaction and dissatisfaction about the sitting order in the lesson. S4, S7, S9, S10, S16, S17, S19 and S20 did not assert any opinion about the order of seating for the activity.

The students' past experiences about the active learning activities were also investigated in this research. Six students informed that they had experienced a lesson like the one experienced in this study. But 14 students were unable to give information that they had experienced an active learning activity. One of the students experienced this kind of activity in an Arabic lesson in the past and 5 of the students experienced this sort of activity in Science lessons beforehand.

\section{RESULT, DISCUSSION, AND SUGGESTIONS}

Generally, the students involved in the research expressed positive emotions and opinions related to the elements of active learning strategy, write share learn strategy. Firstly, $90 \%$ of the students' positive emotions on the active learning activity helped us to recognize the highly emotional superiority of write, share and learn strategy over the traditional conference teaching style. It can be referred that the students' satisfaction on the lesson was compelled to rise by the active learning strategy. Likewise, Adkins (2018) found that students in his study informed their pleasure on formative assessments in a user-centered design as enjoyable and beneficial.

Secondly, higher percentage of students' positive effects of active learning on students' learning over negative effects of active learning on students' learning makes it clear that write, share and learn strategy of active learning pedagogy has an essentially favorable effects on students' learning perceptions. This finding is also supported by Adkins (2018) again. According to Virtanen and colleagues (2017) the utilization of active learning strategies with autonomous and responsible group work are in a positive relationship with achievement of vocational competencies.

Thirdly, the findings show that students mostly have strong positive opinions of their order of seating. Circular order of seating with single seated chairs makes the students feel more comfortable and portable. In the traditional conference seating order all students are faced to the classroom board and the teacher but in a circular order of seating they stated to be happy seeing each other. This situation helps us understand that order of seating in an active learning strategy makes the students more satisfied in their learning atmosphere. Demirci (2003) explained the use of circular seating order as students can interact with each other face to face and students can be asked to reorder the seating for multiple groups work. According to Orak and Demirci (2018) in traditional classroom designs, students take seats in rows so they stay passive in the learning environment but in an active learning atmosphere student can take seats in different positions and interact with each other constantly.

Finally, students' past experience related to active learning strategies were investigated in this study. According to the findings some of the students informed that they had had a lesson in an active learning strategy. Six students reported their experience about their lesson in active learning strategy in the past. When it comes to their lessons' classification in branches, one student had had an Arabic lesson in this kind of lesson and 5 students had had science lesson in active learning strategy. This finding makes us think that science teachers at mid schools are more aware of active learning strategies. If the students are not experienced any lesson with the method of active learning, it is recommended that the students are given a short instruction about the application of active learning method. The strategies used in the active learning are to be mentioned with the examples. 
One of the strongest limitations of this research is that all the students included in this study were male and the study group was comparatively small. At mixed sex-education schools with a bigger study group, more applicable and reliable findings can be achieved. The findings in this investigation generally refers to the students' emotions and opinions about their current active learning experience. An evaluation at the end of each lesson can be performed so as to discuss students' real learning outcomes. The application of this study lasted 5 lesson duration in two weeks. A longer application process like a semester can give more reliable and interpretable findings.

\section{REFERENCES}

Açıkgöz, K. (2003). Aktif Öğrenme, Eğitim Dünyası Yayınları, 5. Edition, İzmir.

Adkins, J. K. (2018). Active learning and formative assessment in a user-centered design course. Information Systems Education Journal, 16(4), 34.

Allen, D., \& Tanner, K. (2005). Infusing active learning into the large-enrollment biology class: seven strategies, from the simple to complex. Cell biology education, 4(4), 262-268.

Armbruster, P., Patel, M., Johnson, E., \& Weiss, M. (2009). Active learning and student-centered pedagogy improve student attitudes and performance in introductory biology. CBE-Life Sciences Education, 8(3), 203-213.

Bain, K. (2004). What the best college teachers do. Cambridge, MA: Harvard University Press.

Bates, R. (2007). The Future of teacher education: challenges and opportunities. Townsend, T. \&Bates, R.(Eds.). Handbook of teacher education: globalization, standards and professionalism in times of change. PO Box 17, 3300 AADordrecht, the Netherlands.

Bonwell, C. C., \& Eison, J. A. (1991). Active Learning: Creating Excitement in the Classroom. 1991 ASHE-ERIC Higher Education Reports. ERIC Clearinghouse on Higher Education, The George Washington University, One Dupont Circle, Suite 630, Washington, DC 20036-1183.

Bruner, J. (1986). Actual minds, possible worlds. Cambridge, MA: Harvard University Press.

Carvalho, A. (2016). The impact of PBL on transferable skills development in management education. Innovations in Education and Teaching International, 53(1), 35-47.

Chickering, A. W., \& Gamson, Z. F. (1987). Seven principles for good practice in undergraduate education. AAHE bulletin, 3, 7 .

Christensen, C. R., Garvin, D. A., \& Sweet, A. (1991). Education for judgment: The artistry of discussion leadership. Cambridge, MA: Harvard Business School.

Demirci, C. (2003). Fen bilgisi öğretiminde etkin öğrenme yaklaşımının erişi, tutum ve kalıcılığa etkisi. Yayınlanmamış Doktora Tezi. Hacettepe Üniversitesi, Sosyal Bilimler Enstitüsü, Ankara.

Demirci, C. (2017). The Effect of active learning approach on attitudes of 7 th grade students. International Journal of Instruction, 10(4), 129-144. https://doi.org/10.12973/iji.2017.1048a

Demirci, C., \& Düzenli, H. (2017). Formative value of an active learning strategy: technology-based think pair-share in an EFL writing classroom. World Journal of Education, 7(6), 63-74. doi:10.1080/14703297.2015.1020327.

Demirci, C., \& Düzenli, H. (2017). Formative Value of an Active Learning Strategy: Technology Based Think Pair Share in an EFL Writing Classroom. World Journal of Education, 7(6), 63-74.

Felder, R. M., \& Brent, R. (2009). Active learning: An introduction. ASQ higher education brief, 2(4), 1-5.

Gillham, B. (2000). Case study research methods. Bloomsbury Publishing. London: Continioum House. 
Harmin, M. (1994). Inspiring active learning: A handbook for teachers. Association for Supervision and Curriculum Development, 1250 North Pitt Street, Alexandria, VA 22314 (Stock No. 1-94027, \$14.95)..

Hyun, J., Ediger, R., \& Lee, D. (2017). Students' Satisfaction on Their Learning Process in Active Learning and Traditional Classrooms. International Journal of Teaching and Learning in Higher Education, 29(1), 108-118.

Khan, A., Egbue, O., Palkie, B., \& Madden, J. (2017). Active Learning: Engaging Students to Maximize Learning In An Online Course. Electronic Journal of E-Learning, 15(2), 107-115.

Lumpkin, A., Achen, R. M., \& Dodd, R. K. (2015). Student perceptions of active learning. College Student Journal, 49(1), 121-133.

Naithani, P. (2008). Reference framework for active learning in higher education. Higher Education in the Twenty-First Century: Issues and Challenges, 113-120.

O'Grady, A., Simmie, G. M., \& Kennedy, T. (2013). Why change to active learning? Pre-service and in-service science teachers' perceptions. European Journal of Teacher Education, 37(1), 35-50.

Orak, S., \& Demirci, C. (2018). Application Examples and Student Views on Active Learning Approach Integrated with Branches of Art. Cypriot Journal of Educational Sciences, 13(1), 53-65.

Prince, M. (2004). Does active learning work? A review of the research. Journal of Engineering Education, 93(3), 223-231. https://doi.org/10.1002/j.2168 9830.2004.tb00809.x

Saban, A. (2000). Öğrenme öğretme süreci. Ankara: Nobel Yayın Dağıtım.

Saban, A., \& Ersoy, A. (2016). Eğitimde Nitel Araştırma Desenleri,(1. Baskı) Ankara: Anı Yayınları.

Scheyvens, R., Griffin, A. L., Jocoy, C. L., Liu, Y., \& Bradford, M. (2008). Experimenting with active learning in geography: Dispelling the myths that perpetuate resistance. Journal of Geography in Higher Education, 32(1), 51-69. https://doi.org/10.1080/03098260701731496

Slavich, G. M., \& Zimbardo, P. G. (2012). Transformational teaching: Theoretical underpinnings, basic principles, and core methods. Educational psychology review, 24(4), 569-608.

Sroufe, R., \& Ramos, D. P. (2015). Leveraging collaborative, thematic problem-based learning to integrate curricula. Decision Sciences Journal of Innovative Education, 13(2), 151-176.

Stover, S., \& Ziswiler, K. (2017). Impact of active learning environments on community of inquiry. International Journal of Teaching and Learning in Higher Education, 29(3), 458-470.

Stover, S., \& Ziswiler, K. (2017). Impact of active learning environments on community of inquiry. International Journal of Teaching and Learning in Higher Education, 29(3), 458-470.

Virtanen, P., Niemi, H. M., \& Nevgi, A. (2017). Active learning and self-regulation enhance student teachers' professional competences. Australian Journal of Teacher Education, 42(12).

Vygotsky, L. S. (1978). Mind in society: The development of higher mental processes (E. Rice, Ed. \& Trans.).

Werner, J. M., Scovotti, C., Cummings, R. G., \& Bronson, J. W. (2018). Building a Case for Active Learning: The Use of Lecture vs. Other Classroom Activities at LMBC. Journal of Learning in Higher Education, 14(1), 7-15. 